\title{
Caffeic acid phenethyl amide improves glucose homeostasis and attenuates the progression of vascular dysfunction in Streptozotocin-induced diabetic rats
}

Yi-Jin Ho ${ }^{1}$, Wen-Pin Chen ${ }^{1}$, Tzong-Cherng Chi ${ }^{2}$, Ching-Chia Chang Chien ${ }^{1}$, An-Sheng Lee ${ }^{3}$, Hsi-Lin Chiu $^{4}$, Yueh-Hsiung Kuo ${ }^{4}$ and Ming-Jai Su ${ }^{1 *}$

\begin{abstract}
Background: Glucose intolerance and cardiovascular complications are major symptoms in patients with diabetes. Many therapies have proven beneficial in treating diabetes in animals by protecting the cardiovascular system and increasing glucose utilization. In this study, we evaluated the effects of caffeic acid phenethyl amide (CAPA) on glucose homeostasis and vascular function in streptozotocin (STZ)-induced type 1 diabetic rats.
\end{abstract}

Methods: Diabetes (blood glucose levels $>350 \mathrm{mg} / \mathrm{dL}$ ), was induced in Wistar rats by a single intravenous injection of $60 \mathrm{mg} / \mathrm{kg}$ STZ. Hypoglycemic effects were then assessed in normal and type 1 diabetic rats. In addition, coronary blood flow in Langendorff-perfused hearts was evaluated in the presence or absence of nitric oxide synthase (NOS) inhibitor. The thoracic aorta was used to measure vascular response to phenylephrine. Finally, the effect of chronic treatment of CAPA and insulin on coronary artery flow and vascular response to phenylephrine were analyzed in diabetic rats.

Results: Oral administration of $0.1 \mathrm{mg} / \mathrm{kg}$ CAPA decreased plasma glucose in normal (32.9 $\pm 2.3 \%$ decrease, $P<0.05)$ and diabetic rats $(11.8 \pm 5.5 \%$ decrease, $P<0.05)$. In normal and diabetic rat hearts, $1-10 \mu \mathrm{M}$ CAPA increased coronary flow rate, and this increase was abolished by $10 \mu \mathrm{M}$ NOS inhibitor. In the thoracic aorta, the concentration/response curve of phenylephrine was right-shifted by administration of $100 \mu \mathrm{M}$ CAPA. Coronary flow rate was reduced to $7.2 \pm 0.2 \mathrm{~mL} / \mathrm{min}$ at 8 weeks after STZ-induction. However, 4 weeks of treatment with CAPA (3 mg/kg, intraperitoneal, twice daily) started at 4 weeks after STZ induction increased flow rate to $11.2 \pm 0.5$ $\mathrm{mL} / \mathrm{min}(P<0.05)$. In addition, the contractile response induced by $1 \mu \mathrm{M}$ phenylephrine increased from $6.8 \pm 0.6$ $\mathrm{mN}$ to $11.4 \pm 0.4 \mathrm{mN}(P<0.05)$ and $14.9 \pm 1.4 \mathrm{mN}(P<0.05)$ by insulin $(1 \mathrm{IJ} / \mathrm{kg}$, intraperitoneal) or CAPA treatment, respectively.

Conclusions: CAPA induced hypoglycemic activity, increased coronary blood flow and vascular response to phenylephrine in type 1 diabetic rats. The increase in coronary blood flow may result from endothelial NOS activation. However, the detailed cellular mechanisms need to be further evaluated.

Keywords: Diabetes, Vascular dysfunction, Caffeic acid phenethyl amide

\footnotetext{
* Correspondence: mingja@ntu.edu.tw

'Institute of Pharmacology, College of Medicine, National Taiwan University,

Taipei, Taiwan

Full list of author information is available at the end of the article
} 


\section{Background}

Diabetes is a metabolic disease resulting from defects in insulin secretion and/or insulin action and is often associated with increased risk of coronary heart disease [1]. Therefore, treating diabetes involves more than glycemic control. Chronic complications are important in diabetes and include nephropathy, neuropathy, retinopathy, and cardiovascular disease [2], with cardiovascular disease, including vascular complications [3] and cardiovascular autonomic neuropathy [4], being the major cause of morbidity and mortality in diabetic patients [5]. In addition, cardiovascular disease is the primary cause of death in patients with either type 1 or type 2 diabetes [6,7]. Patients with type 1 diabetes also bear an increased risk of coronary heart disease, and have a higher mortality from ischemic heart disease at all ages compared to the general population [2]. Therefore, development of therapeutic agents with anti-diabetic and cardiovascular protective activity is urgently required.

To evaluate the pharmacological efficacy of antidiabetic agents, acute or chronic diabetes has been induced in animal models, such as by chemical, surgical, and genetic manipulation [8]. Streptozotocin (STZ) is the most frequently used drug to induce diabetes and has been useful for the study of multiple aspects of the disease [9]. In the cardiovascular system, studies have shown decreased basal coronary arterial flow in STZinduced diabetic mice [10], decreased aortic blood flow in STZ-induced diabetic rats [11], and decreased sensitivity to phenylephrine of vascular tissues in type 1 diabetic rats [12]. In addition, nitric oxide (NO) production is reduced in STZ-induced diabetes, and the decrease in NO may be related to the pathogenesis of diabetic endothelial damage [13]. Normalization of NO synthase activity in type 1 diabetic rats prevents endothelial dysfunction in STZ-induced animals [14]. In long-term STZ-induced diabetic rats, the capacity of the endothelium to synthesize or release NO may decrease and disturb the sensitivity of vascular contractile response to phenylephrine [15].

Currently, effective therapeutic options exist to restore responsiveness to insulin in type 2 diabetes; however, insulin therapy is not only necessary for type 1 diabetes, but also for type 2 diabetes. Most patients with type 2 diabetes will eventually need insulin to achieve diabetes control [16]. Insulin deficiency is a common problem in both type 1 and type 2 diabetes [1]. Therefore, in our study, we used STZ-induced diabetic rats to mimic the clinical state of insulin deficiency and to evaluate new therapeutic agents.

Caffeic acid phenethyl ester (CAPE) is the major component in extracts of propolis and possesses antiinflammatory [17], anti-viral [18], cancer cell inhibitory [19], anti-bacterial, and free radical scavenging activities
[20]. CAPE can improve oxidative stress in diabetic rat hearts [21] and exert its vasorelaxation effect on aorta of rats in vitro $\left(\mathrm{pEC}_{50}, 4.99 \pm 0.19\right.$; Emax, $100.75 \pm$ $1.65 \%$,) [22]. Oral administration of CAPE (30 mg/kg) for 12 weeks ameliorated the atherosclerosis progress in apolipoprotein E-deficient mice [23]. In addition, intraperitoneally injected CAPE $(10 \mu \mathrm{M}) 1 \mathrm{~h}$ before reperfusion attenuated ischemia-reperfusion injury by exerting antioxidant activity in Wistar rats [24]. CAPE significantly decreased the fasting blood levels of glucose, alanine aminotransferase, cholesterol, and triglyceride induced by diabetes [25]. Several natural products exhibit powerful glucose lowering activity, such as caffeic acid [26], extracts of propolis from north China [27], extracts of propolis from Brazil [28], capsaicin [29], and curcumin [30].

Recently, a CAPE analogue, caffeic acid phenethyl amide (CAPA), with amide linkage between caffeic acid and phenethyl group that resists hydrolysis in the circulation, was found to be more stable compared to CAPE in rat plasma [31] and to possess cytoprotective effects against $\mathrm{H}_{2} \mathrm{O}_{2}$-induced cell death in human umbilical vascular endothelial cells [32]. In addition, CAPA has shown $\alpha$-glucosidase inhibitory effects in yeast [33], adiponectin productive activity in 3T3-L1 cells [34], as well as antihyperglycemic activity and cardioprotection effects in diabetic mice $[10,35]$. It also attenuates cardiac dysfunction in abdominal aortic banding-induced cardiac hypertrophy [36], indicating that CAPA may be beneficial to treat diabetes and cardiovascular complications.

The aim of this study was to characterize the acute effect of CAPA on vascular function and glucose homeostasis in normal and type 1 diabetic rats. In addition, the chronic effect of CAPA on vascular dysfunction of type 1 diabetic rats was investigated and compared to that of insulin.

\section{Methods \\ Compound}

To synthesize CAPA (Figure 1), a solution of benzotriazol1-yloxytris (dimethylamino) phosphonium hexafluorophosphate (1.2 equiv) in dichloromethane $\left(\mathrm{CH}_{2} \mathrm{Cl}_{2}\right)(5 \mathrm{~mL})$ was added to a mixture of caffeic acid (100 mg), $\mathrm{R}^{-\mathrm{NH}_{2}}$ (1.2 equiv), and triethylamine $(0.08 \mathrm{~mL})$ in dimethylformamide $(1.0 \mathrm{~mL})$. The mixture was stirred at $0^{\circ} \mathrm{C}$ for $30 \mathrm{~min}$ and then at room temperature for $12 \mathrm{~h}$. This reaction mixture was evaporated under vacuum, and the residue was partitioned between ethyl acetate (AcOEt) and $\mathrm{H}_{2} \mathrm{O}$. The AcOEt layer was washed with $3 \mathrm{~N}$ aqueous $\mathrm{HCl}$ and $10 \%$ $\mathrm{NaHCO}_{3}$ (aq), dried over $\mathrm{MgSO}_{4}$, and vacuum concentrated. The residue was further purified by column chromatography using an eluting solution $\left(\mathrm{CH}_{2} \mathrm{Cl}_{2}\right.$-AcOEt $\left.1: 1, \mathrm{v} / \mathrm{v}\right)$ on silica gel (70-230 and 230-400 mesh, Merck 7734). The final products $(82-88 \%$ yield) were recrystallized from 
<smiles>O=C(/C=C\c1ccc(O)c(O)c1)OCCc1ccccc1</smiles>

Caffeic Acid Phenethyl Ester (CAPE)<smiles>O=C(/C=C\c1ccc(O)c(O)c1)NCCc1ccccc1</smiles>

Caffeic Acid Phenethyl Amide (CAPA)<smiles>O=C(O)/C=C\c1ccc(O)c(O)c1</smiles>

Caffeic acid
(1) $\mathrm{BOP} / \mathrm{Et}_{3} \mathrm{~N} / \mathrm{DMF} / \mathrm{CH}_{2} \mathrm{Cl}_{2}$

(2) $\mathrm{RNH}_{2}$<smiles>CCNC(=O)/C=C\c1ccc(O)c(O)c1</smiles>

CAPA: $\mathrm{R}=-\left(\mathrm{CH}_{2}\right)_{2} \mathrm{Ph}$

Figure 1 The structures of CAPE and CAPA, and the synthetic process of CAPA. CAPA was obtained from the amide binding coupling method, beginning with caffeic acid. CAPA: $\mathrm{R}=-\left(\mathrm{CH}_{2}\right)_{2} \mathrm{Ph}$. benzotriazol-1-yloxytris (dimethylamino) phosphonium hexafluorophosphate (BOP), dichloromethane $\left(\mathrm{CH}_{2} \mathrm{Cl}_{2}\right)$, triethylamine (Et3N), dimethylformamide (DMF).

AcOEt to obtain pure crystals. ${ }^{1} \mathrm{H}$ and ${ }^{13} \mathrm{C}$ nuclear magnetic resonance (NMR) spectra were recorded on a Bruker Avance 500 spectrometer, electron impact mass spectra were determined on a Finnigan TSQ-46C mass spectrometer, and infrared spectra were recorded on a NicoletMagna-IR 550 spectrophotometer. CAPA was obtained from $\mathrm{R}$ substitution with $-\left(\mathrm{CH}_{2}\right)_{2} \mathrm{Ph}$. CAPA: solid; melting point $148-149^{\circ} \mathrm{C}$. Infrared $v_{\max }\left(\mathrm{cm}^{-1}\right)$ : 3288, 1642, 1591, 1523, 1361, 1279, 1036, 975, 849. ${ }^{1} \mathrm{H}$ $\operatorname{NMR}\left(\mathrm{CD}_{3} \mathrm{COCD}_{3}, 500 \mathrm{MHz}\right): \delta 2.84(2 \mathrm{H}, \mathrm{t}, J=6.8 \mathrm{~Hz})$, $3.53(2 \mathrm{H}, \mathrm{q}, J=6.8 \mathrm{~Hz}), 6.43(1 \mathrm{H}, \mathrm{d}, J=15.2 \mathrm{~Hz}), 6.83$ $(1 \mathrm{H}, \mathrm{d}, J=8.1 \mathrm{~Hz}), 6.92(1 \mathrm{H}, \mathrm{dd}, J=8.1,1.8 \mathrm{~Hz}), 7.07(1 \mathrm{H}$, d, $J=1.8 \mathrm{~Hz}), 7.15-7.30(5 \mathrm{H}, \mathrm{m}), 7.35(1 \mathrm{H}, \mathrm{br} \mathrm{s},-\mathrm{NH}), 7.43$ $(1 \mathrm{H}, \quad \mathrm{d}, \quad J=15.2 \mathrm{~Hz}), 8.20(1 \mathrm{H}, \quad \mathrm{s},-\mathrm{OH}), 8.42(1 \mathrm{H}$, s,-OH). EI-MS m/z (\%): 283 (M+17), 178 (22), 163 (100).

\section{Chemicals}

STZ, pentobarbital, N $\omega$-nitro-L-arginine methyl ester (L-NAME), methylene blue, phenylephrine, and dimethylsulfoxide (DMSO) were purchased from SigmaAldrich, USA. The inhibitor of NO-sensitive guanylyl cyclase, ODQ $(1 H-[1,2,4]$ Oxadiazolo [4,3- $a$ ] quinoxalin-1 -one) was purchased from Tocris Bioscience, USA. The chemicals for the physiological solution were purchased from J.T. Baker, Capital Scientific Inc. and Wako Pure Chemical Industries, Japan. Insulin (Insulin Zinc Suspension, Monotard ${ }^{\circ} \mathrm{HM} 100 \mathrm{IU} / \mathrm{mL}$ ) was purchased from Novo Nordisk A/S, Denmark.

\section{Animals}

We used 8-week-old male Wistar rats weighing 250-300 g (bred in a Lab animal center, National Taiwan University, Taiwan) for evaluation of hypoglycemic activity, insulin secretion activity, glucose tolerance test, measurement of coronary arterial flow rate, aortic contractile response, and induction of diabetes. All animal procedures were performed according to the Guide for the Care and Use of Laboratory Animals of the National Institutes of Health, as well as the guidelines of the Animal Welfare Act, and the animal studies were approved with a certificate number 20110073 by the Institutional Animal Care and Use Committee of the College of Medicine, National Taiwan University. For induction of diabetes, rats were anesthetized with sodium pentobarbital $(30 \mathrm{mg} / \mathrm{mL})$, after a 72-h fast [37] and administered STZ (freshly dissolved in sterile, non-pyrogenic $0.9 \% \mathrm{NaCl}$ solution in a volume of $1 \mathrm{~mL} / \mathrm{kg}$ body weight) intravenously through the tail vein at a single dose $(60$ $\mathrm{mg} / \mathrm{kg}$ ) [38]. Two weeks after STZ injection, animals were considered to have type 1 diabetes if they had plasma glucose levels higher than $350 \mathrm{mg} / \mathrm{dL}$ and other diabetic features, such as polyuria, polydipsia, and hyperphagia [39].

\section{Effect of CAPA on plasma glucose in normal and STZ- induced diabetic rats}

We administered CAPA (suspended in distilled water in a volume of $1 \mathrm{~mL} / \mathrm{kg}$ body weight) orally by gavage to overnight-fasted rats at different doses of $0.1 \mathrm{mg} / \mathrm{dL}, 0.5$ $\mathrm{mg} / \mathrm{dL}$, and $1 \mathrm{mg} / \mathrm{dL}$ ( $n=4$ to 11 ). In a previous study, rats that received sodium pentobarbital showed no changes in plasma glucose [40]. Thus, under anesthesia with sodium pentobarbital (30 $\mathrm{mg} / \mathrm{kg}$ intraperitoneal), blood samples $(0.2 \mathrm{~mL})$ were collected from the femoral vein to measure plasma glucose levels. The blood samples were centrifuged at $1000 \mathrm{~g}$ for $5 \mathrm{~min}$, and $10 \mu \mathrm{L}$ of 
clear supernatant serum was added from the $1 \mathrm{~mL}$ glucose kit (Biosystems S.A., Barcelona, Spain). We then estimated the levels of plasma glucose by a spectrophotometer (BTS-330, Biosystems S.A., Barcelona, Spain), run in duplicate [41]. The time course of the effect of CAPA on plasma glucose in STZ-induced diabetic rats was preliminarily determined; the plasma glucoselowering effect of CAPA at an oral dosage of $0.5 \mathrm{mg} / \mathrm{kg}$ reached a plateau within $90 \mathrm{~min}$ and was maintained until $120 \mathrm{~min}$. Thus, we measured the plasma glucose decreasing effects of CAPA using blood samples collected 90 min after oral administration. For the control group, animals were orally administered the same volume of distilled water used in CAPA suspension.

\section{Effects of CAPA on insulin secretion}

We measured plasma insulin levels using an insulin enzyme linked immunosorbent assay (ELISA) kit (Rat Insulin ELISA; Mercodia AB, Uppsala, Sweden) [42]. Briefly, 8-week-old Wistar rats (250-300 g body weight, $n=8)$ were anesthetized with sodium pentobarbital (30 $\mathrm{mg} / \mathrm{kg}$ intraperitoneal), and blood samples $(0.2 \mathrm{~mL})$ were collected from the femoral vein, centrifuged at $1000 \mathrm{~g}$ for $5 \mathrm{~min}$ and $10 \mu \mathrm{L}$ of clear supernatant serum was used to measure plasma insulin levels. After completing the ELISA test procedure, we estimated the levels of insulin using a spectrophotometer (Victor ${ }^{3}$, PerkinElmer Inc., MA, USA); samples were run in duplicate.

\section{Effect of CAPA on intravenous glucose tolerance test}

For the intravenous glucose tolerance test, overnight fasted rats were anesthetized with sodium pentobarbital (30 $\mathrm{mg} / \mathrm{kg}$ intraperitoneal). We administered CAPA (0.5 $\mathrm{mg} / \mathrm{mL} / \mathrm{kg})$ in a volume of $1 \mathrm{~mL} / \mathrm{kg}$ body weight $(n=6)$ or the same volume of distilled water (vehicle treatment, $n=8) 30$ minutes before intravenous injection of glucose (1 g/kg body weight) and measured the blood glucose level at 5, 10, 20, 40, 60, 90, and $120 \mathrm{~min}$ after glucose injection [43].

\section{Effect of CAPA on coronary arterial flow rate in Langendorff-perfused hearts}

The rats were anesthetized with sodium pentobarbital $(50 \mathrm{mg} / \mathrm{kg})$ and given heparin (300 IU/ kg) intraperitoneally. The Langendorff-perfused heart model, using a constant perfusion pressure instead of constant flow rate, was employed [44]. Hearts were rapidly excised and immersed in perfusion medium. After excision of the heart from the chest, the aorta was cannulated and perfused at $80 \mathrm{mmHg}$ with perfusate containing $119.7 \mathrm{mM}$ $\mathrm{NaCl}, 23.8 \mathrm{mM} \mathrm{NaHCO}_{3}, \quad 5.0 \mathrm{mM} \mathrm{KCl}, 0.3 \mathrm{mM}$ $\mathrm{NaH}_{2} \mathrm{PO}_{4}, 1.2 \mathrm{mM} \mathrm{CaCl}, 1.1 \mathrm{mM} \mathrm{MgCl}$, and $5.6 \mathrm{mM}$ glucose. The perfusate was equilibrated with $95 \% \mathrm{O}_{2}, 5 \%$ $\mathrm{CO}_{2}$ at $37^{\circ} \mathrm{C}$. Perfusion pressure and flow rate $(\mathrm{mL} / \mathrm{min})$ were monitored by a MLT844/D pressure transducer (Capto, Horten, Norway), and electrocardiogram was digitally measured during the period of the experiment by a data acquisition device (PowerLab, ADInstruments, Castle Hill, Australia). The 2 tips of the ventricular recording electrode were separated and placed on opposite sides of the ventricular epicardium to generate a bipolar transcardiac electrogram. RR intervals were measured as the average of 6 consecutive cycles to calculate the heart rate as beats per minute [45].

\section{Effect of CAPA on thoracic aorta}

We used the thoracic aorta of rats for vascular contraction response studies. The thoracic aorta were cleaned of adhering periadventitial fat, cut into 3-mm length rings, and then incubated in an organ bath containing Kreb's buffer (composition [in mM]: $\mathrm{NaCl} 118.2, \mathrm{KCl}$ 4.7, $\mathrm{KH}_{2} \mathrm{PO}_{4}$ 1.2, $\mathrm{NaHCO}_{3} 25, \mathrm{MgSO}_{4}$ 1.2, $\mathrm{CaCl}_{2}$ 1.9, and glucose 11.7), with a $\mathrm{pH}$ of 7.4 , and gassed with $95 \%$ $\mathrm{O}_{2}$ and $5 \% \mathrm{CO}_{2}$. The aortic rings were mounted to a polygraph (model RS 3400 recorder, Gould), and contraction force was monitored by a pressure transducer (Type BG 25; Gould, Oxnard, Calif., USA). Aortic rings were equilibrated at a resting tension of $2 \mathrm{~g}$ for $1 \mathrm{~h}$ before the experiments [46]. We evaluated the relaxation effect of CAPA on endothelium-intact and endotheliumdenuded aorta, pre-constricted with phenylephrine $1 \mu \mathrm{M}$ or $\mathrm{KCl} 80 \mathrm{mM}$. Contractile responses were generated by addition of incremental concentrations of phenylephrine (0.001 $\mu \mathrm{M}$ to $10 \mu \mathrm{M})$ on endothelium-denuded aortic rings. The intactness or absence of endothelium was confirmed by the relaxant responses to acetylcholine $(1 \mu \mathrm{M})$ in rings precontracted with phenylephrine $1 \mu \mathrm{M}$ [47].

\section{Vascular effects of CAPA chronic treatment on STZ- induced diabetic rats}

A previous study demonstrated that STZ-induced diabetic mice expressed early vascular dysfunction [48], increased blood glucose stability, and decreased E/A flow ratio [49] after 4 weeks of STZ-induction. We therefore started the therapeutic regimen from this time point (4 weeks). There were 3 treatment groups of diabetic rats: vehicle-treated group $(0.1 \mathrm{~mL} / \mathrm{kg} \mathrm{DMSO})$, insulintreated group (1 IU/kg insulin), and CAPA-treated group (3 $\mathrm{mg} / \mathrm{kg}$ CAPA). All groups were administered the agents intraperitoneally twice daily for 4 weeks. The control group consisted of age- and sex-matched normal Wistar rats.

\section{Data analysis}

Values are expressed as means \pm SEM of $n$ observations, where $n$ represents the number of animals studied. The data were subjected to ANOVA followed by a multiplecomparison test (Bonferroni's test) or analyzed by 
unpaired Student's $t$-test. $P<0.05$ was considered to be statistically significant.

\section{Results \\ CAPA decreased plasma glucose levels in normal and STZ-induced diabetic rats}

The effect of CAPA on plasma glucose levels was measured in anesthetized overnight-fasted rats. The maximum plasma glucose lowering effect was observed at 90 minutes after oral administration of $0.1 \mathrm{mg} / \mathrm{kg}$ CAPA $(n=7)$ compared to vehicle treatment $(n=8)$ (percent decrease in glucose level, $32.9 \pm 2.3 \%$ vs. $5.8 \pm 5.7 \%, P<$ 0.05 ) (Table 1). The plasma glucose lowering effect of CAPA in normal rats was not dose dependent (32.8 \pm $3.4 \%, n=6$ and $29.5 \pm 1.7 \%, n=6$ after oral administration of $0.5 \mathrm{mg} / \mathrm{kg}$ and $1 \mathrm{mg} / \mathrm{kg}$ CAPA, respectively). Obvious plasma glucose lowering activity was observed after oral administration of $0.1 \mathrm{mg} / \mathrm{kg}$ CAPA in STZinduced type 1 diabetic rats $(11.8 \pm 5.5 \%, n=4, P<0.05$ compared to vehicle treatment, $0.6 \pm 0.1 \%, n=8)$. No further increase in plasma glucose lowering activity was observed when the dose was increased to $0.5 \mathrm{mg} / \mathrm{kg}$ and $1.0 \mathrm{mg} / \mathrm{kg}(13.8 \pm 4.3 \%, n=7$ and $11.6 \pm 1.7 \%, n=11$, respectively).

\section{CAPA increased insulin secretion}

Insulin secretion was measured in overnight fasted and anesthetized rats. Plasma insulin concentration increased after 30 minutes from a mean value of $7.7 \pm 1.0 \mu \mathrm{IU} / \mathrm{mL}$ to $14.9 \pm 3.4 \mu \mathrm{IU} / \mathrm{mL}(n=8)$ after oral administration of $1 \mathrm{mg} / \mathrm{kg}$ CAPA (Table 2).

\section{CAPA improved glucose tolerance}

The plasma glucose levels of CAPA $(0.5 \mathrm{mg} / \mathrm{kg})$-treated rats $(n=6)$ were $112.2 \pm 4.3,100.5 \pm 3.6,91.7 \pm 2.1$, and $93.2 \pm 2.7 \mathrm{mg} / \mathrm{dL}$ at $40,60,90$, and 120 minutes after intravenous glucose $(1000 \mathrm{mg} / \mathrm{kg})$ injection, respectively; these levels were significantly $(P<0.05)$ lower than those of the distilled water treated group $(174.0 \pm 15.4 \mathrm{mg} / \mathrm{dL}$,
Table 2 Effect of CAPA on plasma insulin levels in normal rats

\begin{tabular}{|c|c|c|c|}
\hline \multicolumn{4}{|c|}{ Plasma insulin } \\
\hline $\begin{array}{c}\text { CAPA } \\
(\mathrm{mg} / \mathrm{kg})\end{array}$ & $\begin{array}{l}\text { Pre-treatment } \\
(\mu \mathrm{IU} / \mathrm{mL})\end{array}$ & $\begin{array}{l}\text { Post-treatment } \\
(\mu \mathrm{I} \mathrm{U} / \mathrm{mL})\end{array}$ & $\bar{n}$ \\
\hline 1 & $7.7 \pm 1.0$ & $14.9 \pm 3.4^{*}$ & 8 \\
\hline
\end{tabular}

Plasma insulin was measured at $30 \mathrm{~min}$ after oral administration of CAPA $(1 \mathrm{mg} / \mathrm{kg}$ ) in overnight fasted rats. Data (mean \pm SEM) were obtained from 8 animals. ${ }^{*} P<0.05$ compared with the pre-treatment animals and examined by the paired $t$-test.

$138.0 \pm 12.4 \mathrm{mg} / \mathrm{dL}, 155.0 \pm 25.3 \mathrm{mg} / \mathrm{dL}$, and $156.0 \pm$ $25.7 \mathrm{mg} / \mathrm{dL}$, respectively, $n=8$, Figure 2).

\section{CAPA increased coronary arterial flow rate}

Coronary arterial flow rate was measured 20 minutes after perfusion with a solution containing 1,3 , or 10 $\mu \mathrm{M}$ CAPA. The flow rate of perfused hearts compared to normal rats was shown to be increased by $1 \mu \mathrm{M}$ CAPA from $11.8 \pm 1.0 \mathrm{~mL} / \mathrm{min}$ to $15.6 \pm 1.2 \mathrm{~mL} / \mathrm{min}$. Furthermore, coronary arterial flow rate dosedependently increased to $17.4 \pm 1.3 \mathrm{~mL} / \mathrm{min}$ and $19.5 \pm$ $0.7 \mathrm{~mL} / \mathrm{min}$ following injection of 3 and $10 \mu \mathrm{M}$ CAPA, respectively (Table 3). CAPA 1,3 , and $10 \mu \mathrm{M}$ also increased the coronary arterial flow rate in the hearts of STZ-induced type 1 diabetic rats from $10.3 \pm 0.6$ $\mathrm{mL} / \mathrm{min}$ to $11.9 \pm 0.9 \mathrm{~mL} / \mathrm{min}, 13.3 \pm 1.1 \mathrm{~mL} / \mathrm{min}$, and $14.8 \pm 1.4 \mathrm{~mL} / \mathrm{min}$, respectively. This increase in coronary arterial flow rate, however, was less than that in normal rats. The heart rate of animals during all experiments did not significantly change (Table 3 ). Both the basal coronary arterial flow rate and the coronary arterial flow rate in the presence of CAPA $(1,3$, or 10 $\mu \mathrm{M})$ in normal rats were significantly reduced by $\mathrm{L}$ NAME $(10 \mu \mathrm{M})$, a nitric oxide synthase (NOS) inhibitor, from $10.8 \pm 0.8 \mathrm{~mL} / \mathrm{min}, 13.2 \pm 0.8 \mathrm{~mL} / \mathrm{min}, 14.0 \pm$ $1.0 \mathrm{~mL} / \mathrm{min}$, and $16.8 \pm 1.2 \mathrm{~mL} / \mathrm{min}$ to $5.5 \pm 0.7 \mathrm{~mL} /$ $\mathrm{min}, 5.8 \pm 0.8 \mathrm{~mL} / \mathrm{min}, 6.6 \pm 0.7 \mathrm{~mL} / \mathrm{min}$, and $7.4 \pm 0.8$ $\mathrm{mL} / \mathrm{min}$, respectively (Figure $3 \mathrm{~A}$ and normalized response in Figure 3B). The increase in coronary arterial

Table 1 Effect of CAPA on plasma glucose levels in normal and diabetic rats

\begin{tabular}{|c|c|c|c|c|c|c|c|c|}
\hline \multirow{3}{*}{$\begin{array}{l}\text { CAPA } \\
(\mathrm{mg} / \mathrm{kg})\end{array}$} & \multicolumn{4}{|c|}{ Normal rats } & \multicolumn{4}{|c|}{ Type 1 diabetic rats } \\
\hline & \multicolumn{2}{|c|}{ Plasma glucose } & \multirow{2}{*}{$\begin{array}{c}\% \text { decrease } \\
\text { in plasma } \\
\text { glucose }\end{array}$} & \multirow[t]{2}{*}{$\bar{n}$} & \multicolumn{2}{|c|}{ Plasma glucose } & \multirow{2}{*}{$\begin{array}{c}\% \text { decrease } \\
\text { in plasma } \\
\text { glucose }\end{array}$} & \multirow[t]{2}{*}{$\bar{n}$} \\
\hline & $\begin{array}{l}\text { Pre-treatment } \\
(\mathrm{mg} / \mathrm{dL})\end{array}$ & $\begin{array}{l}\text { Post-treatment } \\
\text { (mg/dL) }\end{array}$ & & & $\begin{array}{l}\text { Pre-treatment } \\
\text { (mg/dL) }\end{array}$ & $\begin{array}{l}\text { Post-treatment } \\
\text { (mg/dL) }\end{array}$ & & \\
\hline Vehicle & $138.5 \pm 5.9$ & $129.3 \pm 2.2$ & $5.8 \pm 5.7$ & 8 & $446.6 \pm 11.6$ & $444.1 \pm 11.6$ & $0.6 \pm 0.1$ & $\overline{8}$ \\
\hline 0.1 & $124.3 \pm 4.6$ & $83.1 \pm 3.7^{*}$ & $32.9 \pm 2.3 *$ & 7 & $469.8 \pm 37.2$ & $409.8 \pm 37.9$ & $11.8 \pm 5.5 *$ & 4 \\
\hline 0.5 & $120.5 \pm 5.3$ & $81.0 \pm 5.7^{*}$ & $32.8 \pm 3.4 *$ & 6 & $461.7 \pm 21.3$ & $394.0 \pm 13.5 *$ & $13.8 \pm 4.3 *$ & 7 \\
\hline 1 & $126.2 \pm 2.0$ & $89.0 \pm 3.2 *$ & $29.5 \pm 1.7 *$ & 6 & $447.4 \pm 25.5$ & $393.7 \pm 20.6$ * & $11.6 \pm 1.7 *$ & 11 \\
\hline
\end{tabular}

Plasma glucose was measured at 90 min after oral administration of vehicle or CAPA in overnight fasted rats. Rats treated with vehicle were used as controls. Data (mean \pm SEM) were obtained from $4-11$ animals. ${ }^{*} P<0.05$ compared with the vehicle control group and examined by the paired $t$-test. 


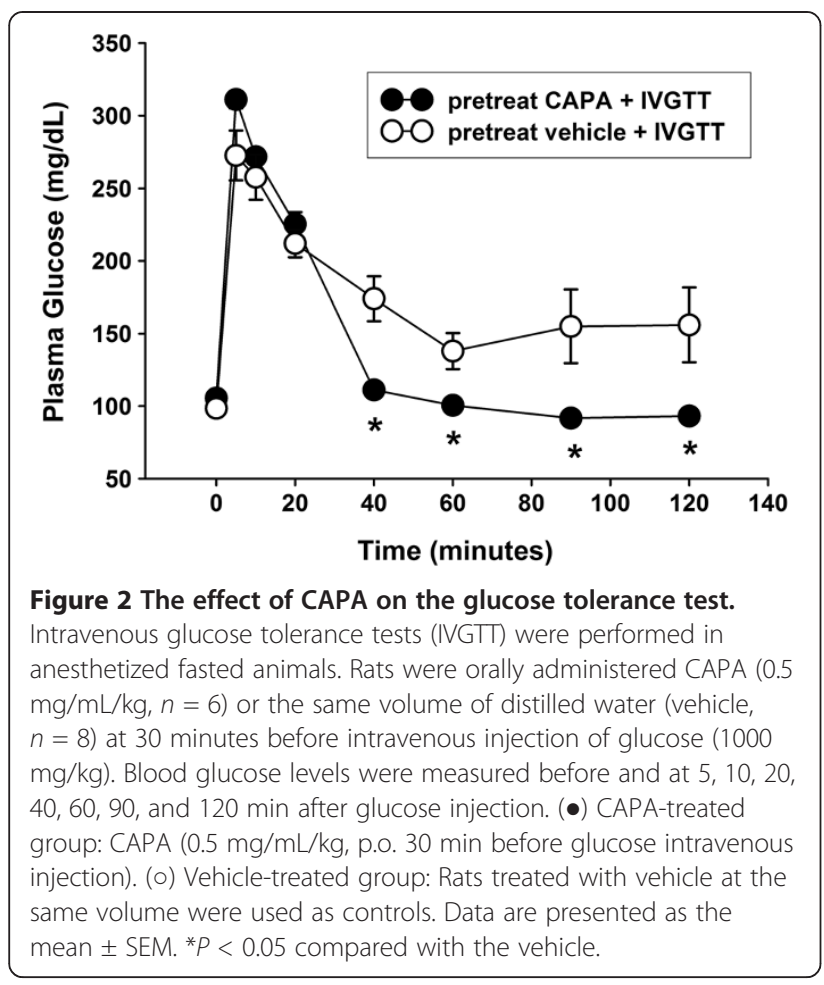

flow rate by 1 and $3 \mu \mathrm{M}$ CAPA was mostly abolished by $10 \mu \mathrm{M}$ L-NAME.

CAPA relaxed the thoracic aorta and shifts the doseresponse curve of Phenylephrine-induced contraction CAPA showed concentration-dependent inhibition of endothelium-intact and endothelium-denuded rat thoracic aorta, constriction induced by $80 \mathrm{mM}$ potassium or $1 \mu \mathrm{M}$ phenylephrine (Figure 4A and Figure 4B). These vasorelaxant effects precontracted with phenylephrine were not affected by $10 \mu \mathrm{M}$ NOS inhibitor (L-NAME), $10 \mu \mathrm{M}$ NO-sensitive guanylyl cyclase selective inhibitor (ODQ), or $100 \mu \mathrm{M}$ soluble guanylyl cyclase inhibitor

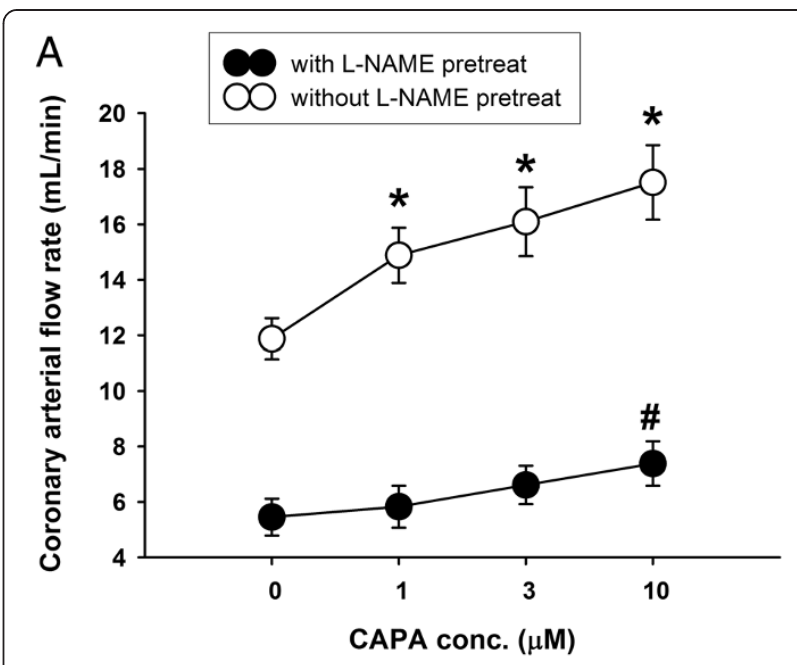

$\mathrm{B}$

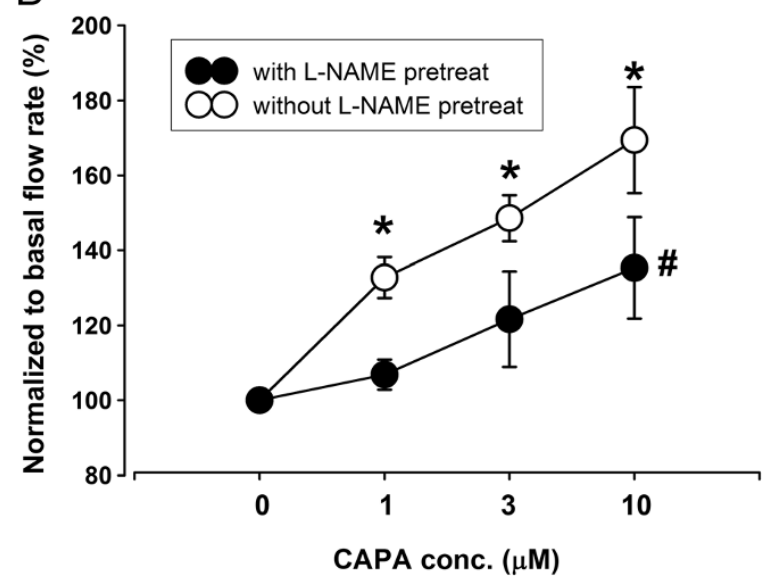

Figure 3 Effect of CAPA on coronary arterial flow rate in normal or L-NAME-treated rat hearts. Coronary arterial flow rate $(\mathrm{mL} / \mathrm{min})$ was measured after 30 min of equilibrium with retrograde perfusion using a constant pressure of $80 \mathrm{mmHg}$. The L-NAMEtreated hearts were perfused with $10 \mu \mathrm{M}$ L-NAME (A), and data were normalized to basal flow rate (B). Data (mean \pm SEM) were obtained from 4-9 animals. ${ }^{*} P<0.05$ compared with the untreated control of normal rat hearts and ${ }^{\#} P<0.05$ compared with the untreated control of the L-NAME group.

Table 3 Effect of CAPA on the coronary arterial flow rate and heart rate

\begin{tabular}{|c|c|c|c|c|c|c|}
\hline \multirow{2}{*}{$\begin{array}{c}\text { CAPA } \\
(\mu \mathrm{M})\end{array}$} & \multicolumn{3}{|c|}{ Normal rat hearts } & \multicolumn{3}{|c|}{ Type 1 diabetic rat hearts } \\
\hline & Coronary arterial flow rate $(\mathrm{mL} / \mathrm{min})$ & Heart rate (BPM) & $\mathbf{n}$ & Coronary arterial flow rate $(\mathrm{mL} / \mathrm{min})$ & Heart rate (BPM) & $\mathrm{n}$ \\
\hline 0 & $11.8 \pm 1.0$ & $236.1 \pm 7.1$ & 5 & $10.3 \pm 0.6$ & $207.8 \pm 12.9$ & 9 \\
\hline 1 & $15.6 \pm 1.2 *$ & $234.2 \pm 11.7$ & 5 & $11.9 \pm 0.9 *$ & $208.5 \pm 11.1$ & 9 \\
\hline 3 & $17.4 \pm 1.3 *$ & $234.1 \pm 6.5$ & 5 & $13.3 \pm 1.1 *$ & $203.2 \pm 9.2$ & 8 \\
\hline 10 & $19.5 \pm 0.7 *$ & $218.0 \pm 5.5$ & 4 & $14.8 \pm 1.4 *$ & $205.5 \pm 10.2$ & 6 \\
\hline
\end{tabular}

Effect of CAPA on the coronary arterial flow rate $(\mathrm{mL} / \mathrm{min})$ and heart rate (BPM: beats per minute) in normal and type 1 diabetic rat hearts. Coronary arterial flow rate was measured after $30 \mathrm{~min}$ of equilibrium with retrograde perfusion at a constant pressure of $80 \mathrm{mmHg}$. Data (mean $\pm \mathrm{SEM}$ ) were obtained from 4-9 animals. $* P<0.05$ compared with CAPA $(0 \mu \mathrm{M})$-administered animals. 

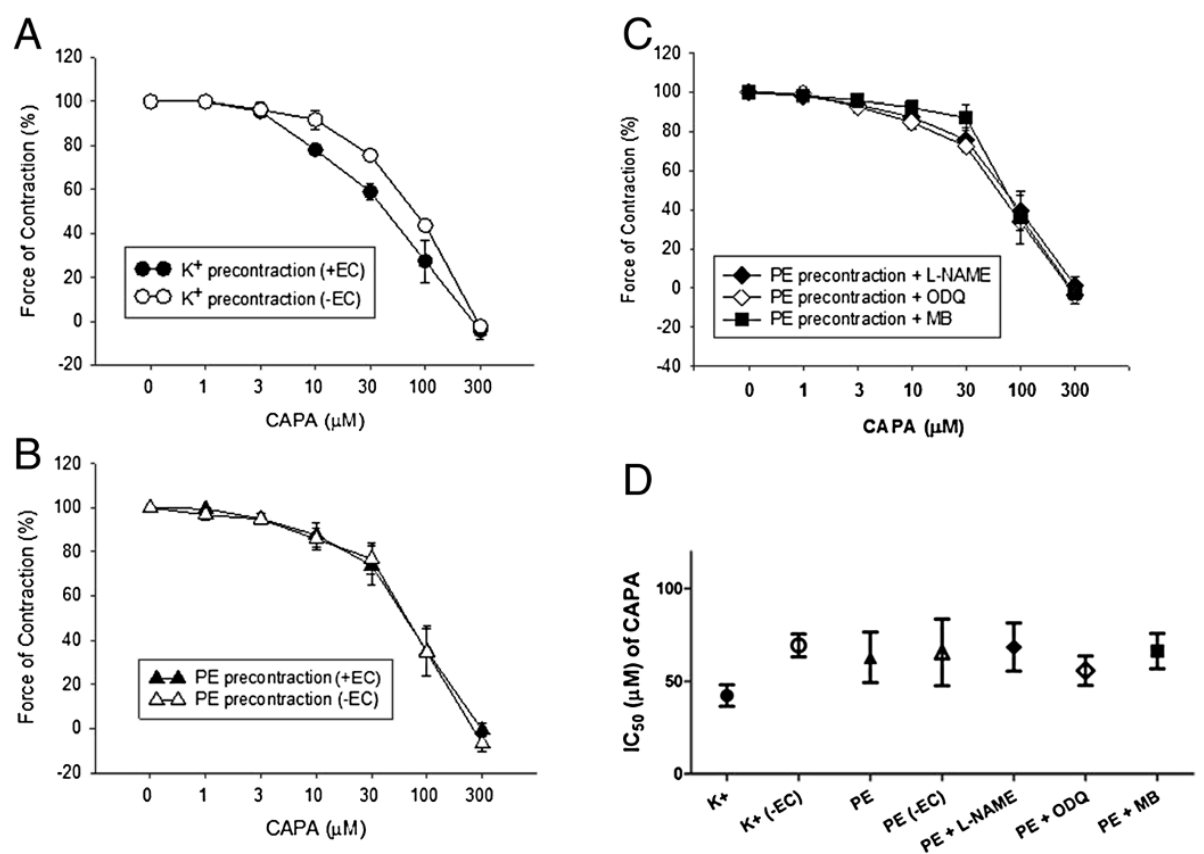

Figure 4 Concentration-dependent inhibition of CAPA on thoracic aorta, constriction-induced by high concentration potassium or phenylephrine. The relaxation effect of CAPA was measured in endothelium-intact (+EC) and endothelium-denuded (-EC) thoracic aorta. The aortic strips were pre-constricted with high concentration of potassium ( $80 \mathrm{mM}$ ) (A) or $1 \mu \mathrm{M}$ phenylephrine (B), pre-treated with inhibitors (C), such as $10 \mu \mathrm{M}$ NOS inhibitor (L-NAME), $10 \mu \mathrm{M}$ nitric oxide-sensitive guanylyl cyclase selective inhibitor (ODQ), and $100 \mu \mathrm{M}$ soluble guanylyl cyclase inhibitor (MB), and CAPA was added in a cumulated concentrations in the organ bath to assess relaxation effects. The $I C_{50}$ values for CAPA are shown in (D). Data (mean \pm SEM) were obtained from 6-8 animals.

methylene blue (Figure $4 \mathrm{C}$ ). The $\mathrm{IC}_{50}$ values for inhibition of vasoconstriction are shown in Figure 4D, with no significant differences seen among them. The concentration-response curve of endothelium-denuded aortic strips to phenylephrine demonstrated a significant right shift (Figure 5A and normalized response in Figure $5 \mathrm{~B}$ ), and the $\mathrm{EC}_{50}$ of phenylephrine was significantly increased by $100 \mu \mathrm{M}$ CAPA $\left(\mathrm{EC}_{50}=347.7 \pm 120.9\right.$ $\mathrm{nM}$ ) (Figure 5C); the Hill coefficient of phenylephrineinduced contraction remained unchanged (Figure 5D).

\section{CAPA attenuated the progression of vascular dysfunction in STZ-induced diabetic rats}

Compared to a coronary arterial flow rate of $12.6 \pm 0.5$ $\mathrm{mL} / \mathrm{min}(n=6)$ in control normal rats, the mean flow rate in diabetic rats at 8 weeks after STZ induction was reduced to $7.2 \pm 0.2 \mathrm{~mL} / \mathrm{min}(n=4, P<0.05)$. However, twice daily treatment with CAPA $(3 \mathrm{mg} / \mathrm{kg}$, intraperitoneal) in diabetic rats $(n=5$, started at 4 weeks after STZ induction) for 4 weeks significantly increased coronary arterial flow rate to $11.2 \pm 0.5 \mathrm{~mL} / \mathrm{min}(P<0.05$ compared with STZ-vehicle treatment) (Figure 6A). In addition, the contractile force induced by $1 \mu \mathrm{M}$ phenylephrine was significantly decreased in the STZ-vehicle group (from $13.2 \pm 0.9 \mathrm{mN}$ to $6.8 \pm 0.6 \mathrm{mN}, n=4, P<$ $0.05)$, but increased from $6.8 \pm 0.6 \mathrm{mN}$ to $11.4 \pm 0.4 \mathrm{mN}$ $(n=4)$ and $14.9 \pm 1.4 \mathrm{mN}(n=6)$ by insulin or CAPA treatment, respectively $(P<0.05$ compared with STZvehicle treatment) (Figure 6B).

\section{Discussion}

CAPA was found to decrease plasma glucose levels in normal and diabetic rats. Decreased plasma glucose levels in normal rats are associated with both enhancement of insulin secretion and glucose utilization. Several pharmacological agents such as $\mathrm{K}_{\text {ATP }}$ channel inhibitors [50], Glucagon-like peptide-1 and dipeptidyl peptidase IV (DPP-IV) inhibitors [51], are known to exert their hypoglycemic action via enhancement of insulin release. In a previous study, we tested the effect of CAPA on DPP-IV activity and $\mathrm{K}_{\mathrm{ATP}}$ potassium current in a pancreatic beta cell line, MIN6. CAPA did not inhibit DPP-IV activity, but was found to inhibit $\mathrm{K}_{\mathrm{ATP}}$ channels with a calculated $\mathrm{IC}_{50}$ of $21.2 \mu \mathrm{M}$ (data not shown). Since the calculated maximal plasma concentration after oral administration of CAPA at $0.5 \mathrm{mg} / \mathrm{kg}$ is less than $1.8 \mu \mathrm{M}$, the stimulation of insulin secretion after oral administration can only partly be attributed to its inhibition of $\mathrm{K}_{\mathrm{ATP}}$ channels. In addition, in the present study, CAPA was found to inhibit $\alpha$-adrenergic receptors on vascular tissue. Since inhibition of sympathetic $\alpha$-adrenergic receptors is reported to enhance insulin release [52], the 

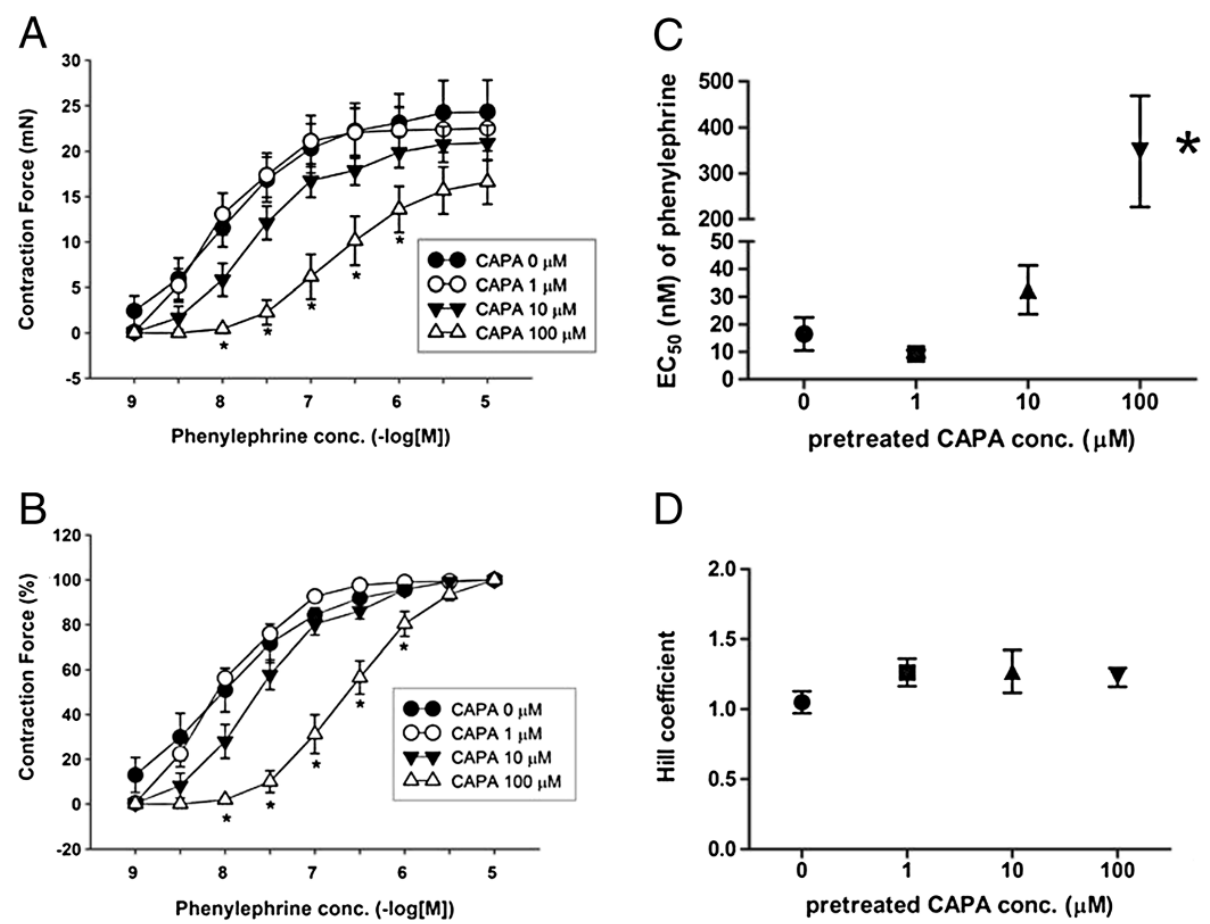

Figure 5 Effect of CAPA on concentration-dependent contractile response to phenylephrine in endothelium-denuded aortic strips. The effect of CAPA on the contractile response to phenylephrine was measured in endothelium-denuded thoracic aorta. The aortic strips were pretreated with 1, 10 and $100 \mu \mathrm{M}$ CAPA, and phenylephrine was added in a cumulative dose in the organ bath (A). Normalized contraction to the maximum response of phenylephrine is shown (B). The $\mathrm{EC}_{50}$ values for phenylephrine and the Hill coefficient are shown in (C) and (D). Data (mean \pm SEM) were obtained from 6-8 animals. ${ }^{*} P<0.05$ compared with the vehicle, DMSO pre-treatment group.

stimulation of insulin release by CAPA may be partly attributed to inhibition of $\alpha$-adrenoceptors. In STZinduced type 1 diabetic rats, CAPA lowered plasma glucose levels even though this diabetic rat model has low insulin secretion activity, suggesting that insulinindependent mechanisms may be involved. Our findings were concordant with those studies that reported plasma glucose lowering activity of CAPA in STZ-induced type 1 diabetic mice [35] and increased glucose transporter 4 protein expression along with insulin-induced glycogen synthesis in diet-induced type 2 diabetic mice [10]. The detailed mechanism responsible for the antidiabetic activity in type 1 diabetic rats remains to be investigated.

Diabetes is associated with several cardiovascular risk factors, such as abnormal glycemia, lipidemia, visceral obesity, and oxidative stress, which impair endothelial function and predispose patients to macrovascular disease, including coronary artery disease and cerebral vascular disease, ultimately the major causes of morbidity and mortality in diabetic patients [2]. A previous study showed that CAPA has cytoprotective effects on human umbilical vein endothelial cells [32]. In the present study, we found that 1 and $3 \mu \mathrm{M} \mathrm{CAPA}$ increased coronary blood flow in a Langendorff-perfused heart model. In addition, we observed that the CAPA-induced increase in coronary blood flow was prevented by an NOS inhibitor. Our results suggest that CAPA may enhance coronary blood flow by increasing the availability or level of NO.

Our results suggest that CAPA may enhance coronary flow by increasing the availability of NO in the coronary artery. The 2,2-diphenyl-1-picrylhydrazyl radical scavenging activity of CAPA, as shown by an $\mathrm{EC}_{50}$ of $18.6 \pm 3.2$ $\mu \mathrm{M}$ (comparable to the $\mathrm{EC}_{50}$ of $15.6 \pm 2.0 \mu \mathrm{M}$ of CAPE, data not shown), may reduce tissue oxidative stress and increase tissue availability of NO. In addition, our studies in type 2 diabetic mice show that CAPA treatment could increase manganese superoxide dismutase in fat tissue [10], but whether this effect occurs in the coronary vascular bed remains unknown.

Higher concentrations of CAPA were found to relax the thoracic aorta following potassium- or phenylephrineinduced constriction. None of the inhibitors of the NO signaling pathway was able to block the vasorelaxant activity of CAPA (Figure 4), but the concentration-response curve to phenylephrine was shifted to the right in the presence of CAPA (Figure 5), suggesting that high concentrations of CAPA may have $\alpha$-receptor blocking activity. Because of the relatively low $\alpha$-adrenergic receptor blocking activity of CAPA, no changes in blood pressure 


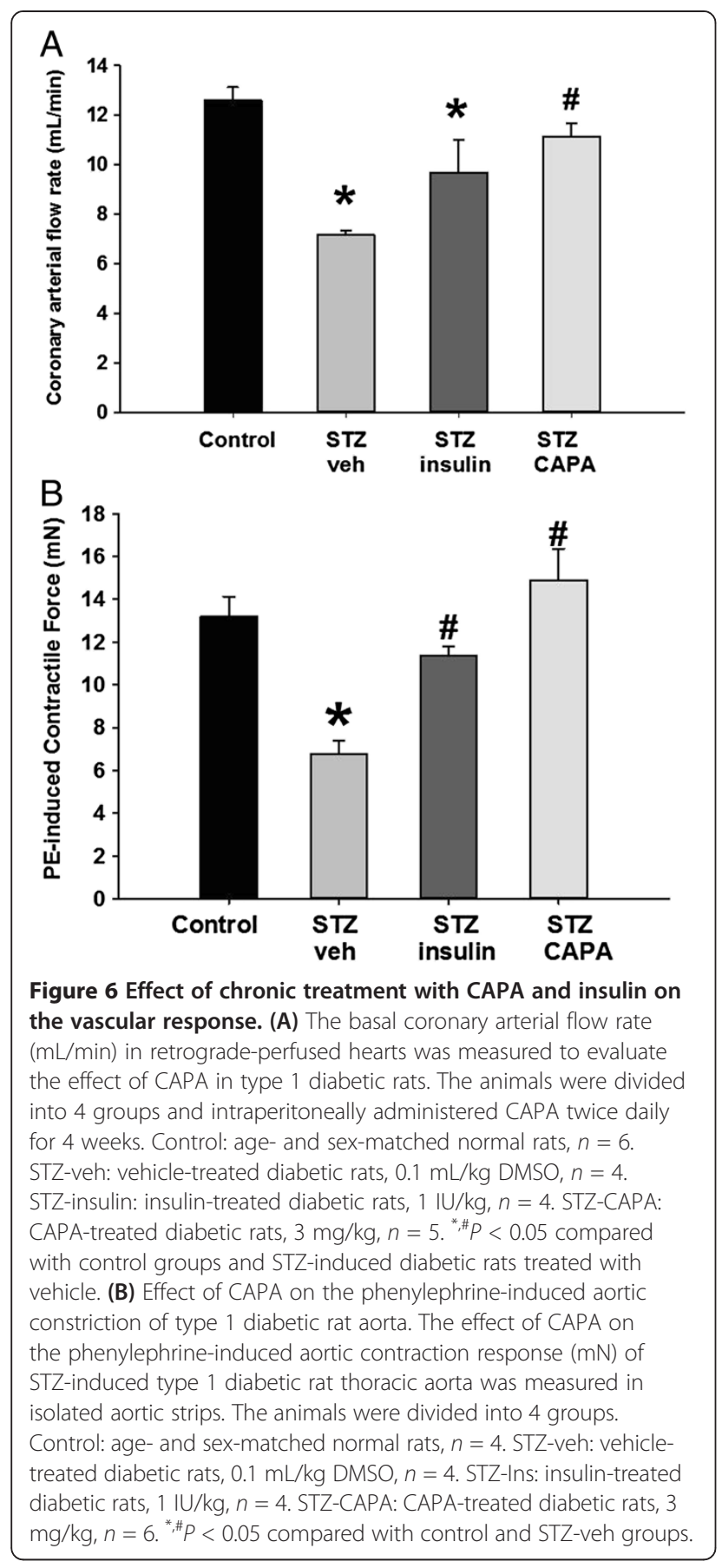

were seen after oral administration of 1,5 , and $10 \mathrm{mg} / \mathrm{kg}$ CAPA in the tail cuff plethysmography experiment (data not shown).

With regard to potassium-induced thoracic aorta constriction, CAPA administration relaxed denuded thoracic aorta as shown by an $\mathrm{IC}_{50}$ of approximately $75 \mu \mathrm{M}$. In endothelium-intact thoracic aorta, CAPA relaxed the thoracic aorta with an $\mathrm{IC}_{50}$ of $45 \mu \mathrm{M}$. This finding suggests that enhancement of endothelium-dependent $\mathrm{NO}$ production may contribute to the relaxant effect of
CAPA in endothelium-intact aorta. The relaxant effect of CAPA on potassium-induced constriction in denuded aorta may be mediated by direct inhibition of L-type $\mathrm{Ca}^{2+}$ channels in smooth muscle. However, this remains to be investigated.

This study showed that CAPA has potent plasma glucose lowering and coronary artery dilation effects without influencing heart rate and blood pressure. We found decreased plasma glucose levels and increased coronary dilation in CAPA-treated rats; whether CAPA-enhanced vasodilation occurs in blood vessel flow through other tissues remains unknown.

STZ-induced diabetic rats showed decreased autonomic activity and coronary artery perfusion [53]. Our study strongly suggests that CAPA is a powerful candidate for treating vascular disease in diabetic patients.

\section{Conclusions}

CAPA, a compound derived from CAPE, the active component in propolis, shows more structural stability than CAPE and lowers plasma glucose levels and exerts coronary artery dilation effects in normal and diabetic rats. CAPA also ameliorates vascular dysfunction in diabetic rats, suggesting that it could be a good candidate for the treatment of vascular complications in diabetic patients. Since the major complication in diabetes is cardiovascular dysfunction, further studies on cardiac functions, such as on the contractile response in cardiomyocytes, in vivo cardiac hemodynamic function, and underlying molecular mechanisms are required.

\section{Competing interests}

The authors declare that they have no competing interests.

\section{Authors' contributions}

Participated in research design: M-JS, and W-PC; Conducted experiments: diabetic animal induction, hypoglycemic activity measurement, insulin level measurement and intravenous glucose tolerance test: $\mathrm{Y}-\mathrm{JH}$ and $\mathrm{T}-\mathrm{CC}$; vasomotor activity measurement: $Y-J H$ and C-CCC; retrograde-perfused heart: Y-JH and A-SL; $K_{\text {ATP }}$ channel activity in MIN6 cell: W-PC; synthesis, purification of new compound: H-LC and Y-HK; performed data analysis: Y-JH, W-PC and M-JS; Wrote or contributed to the writing of the manuscript: Y-JH, W-PC, ASL, and M-JS. All authors read and approved the final manuscript.

\section{Acknowledgements}

The source of financial support: This work was supported by National Science Council, Taiwan (NSC 94-2323-B-002-011, NSC 98-2323-B-002-014CC2, NSC 101-2325-B-002-058).

\section{Author details}

'Institute of Pharmacology, College of Medicine, National Taiwan University, Taipei, Taiwan. ${ }^{2}$ Graduate Institute of Medical Sciences, Chang Jung Christian University, Tainan, Taiwan. ${ }^{3}$ Department of Medicine, Mackay Medical

College, New Taipei, Taiwan. ${ }^{4}$ Tsuzuki Institute for Traditional Medicine, China Medical University, Taichung, Taiwan.

Received: 16 April 2013 Accepted: 30 June 2013

Published: 6 July 2013

\section{References}

1. American Diabetes Association: Diagnosis and classification of diabetes mellitus. Diabetes Care 2012, 35(Suppl 1):S64-71. 
2. Fowler MJ: Microvascular and macrovascular complications of diabetes. Clinical Diabetes 2008, 26:77-82.

3. Schalkwijk CG, Stehouwer CD: Vascular complications in diabetes mellitus: the role of endothelial dysfunction. Clin Sci (Lond) 2005, 109:143-159.

4. Maser RE, Lenhard MJ: Cardiovascular autonomic neuropathy due to diabetes mellitus: clinical manifestations, consequences, and treatment. J Clin Endocrinol Metab 2005, 90:5896-5903.

5. Eckel RH, Kahn R, Robertson RM, Rizza RA: Preventing cardiovascular disease and diabetes: a call to action from the american diabetes association and the american heart association. Circulation 2006, 113:2943-2946.

6. Laing SP, Swerdlow AJ, Slater SD, Burden AC, Morris A, Waugh NR, Gatling W, Bingley PJ, Patterson CC: Mortality from heart disease in a cohort of 23,000 patients with insulin-treated diabetes. Diabetologia 2003, 46:760-765.

7. Paterson AD, Rutledge BN, Cleary PA, Lachin JM, Crow RS: The effect of intensive diabetes treatment on resting heart rate in type 1 diabetes: the diabetes control and complications trial/epidemiology of diabetes interventions and complications study. Diabetes Care 2007, 30:2107-2112.

8. Kumar S, Singh R, Vasudeva N, Sharma S: Acute and chronic animal models for the evaluation of anti-diabetic agents. Cardiovasc Diabetol 2012, 11:9.

9. Rydgren T, Vaarala O, Sandler S: Simvastatin protects against multiple lowdose streptozotocin-induced type 1 diabetes in CD-1 mice and recurrence of disease in nonobese diabetic mice. J Pharmacol Exp Ther 2007, 323:180-185.

10. Weng YC, Chuang ST, Lin YC, Chuang CF, Chi TC, Chiu HL, Kuo YH, Su MJ: Caffeic acid phenylethyl amide protects against the metabolic consequences in diabetes mellitus induced by diet and streptozocin. Evid Based Complement Alternat Med 2012, 2012:984780.

11. Mar GYKP, Chen LJ, Cheng KC, Li YX, Cheng JT: Increase in cardiac M2muscarinic receptor expression is regulated by GATA binding protein 4 (GATA-4) in streptozotocin-induced diabetic rats. Int I Cardiol 2013, 167:436-441.

12. Aloysius Ul, Achike Fl, Mustafa MR: Mechanisms underlining gender differences in phenylephrine contraction of normoglycaemic and shortterm streptozotocin-induced diabetic WKY rat aorta. Vascul Pharmacol 2012, 57:81-90.

13. Felaco M, Grilli A, De Lutiis MA, Patruno A, Libertini N, Taccardi AA, Di Napoli P, Di Giulio C, Barbacane R, Conti P: Endothelial nitric oxide synthase (eNOS) expression and localization in healthy and diabetic rat hearts. Ann Clin Lab Sci 2001, 31:179-186.

14. Serizawa K, Yogo K, Aizawa K, Tashiro Y, Ishizuka N: Nicorandil prevents endothelial dysfunction due to antioxidative effects via normalisation of $\mathrm{NADPH}$ oxidase and nitric oxide synthase in streptozotocin diabetic rats. Cardiovasc Diabetol 2011, 10:105.

15. Chang KS, Stevens WC: Endothelium-dependent increase in vascular sensitivity to phenylephrine in long-term streptozotocin diabetic rat aorta. Br J Pharmacol 1992, 107:983-990.

16. Swinnen SG, Hoekstra JB, DeVries JH: Insulin therapy for type 2 diabetes. Diabetes Care 2009, 32(Suppl 2):S253-259.

17. Toyoda T, Tsukamoto T, Takasu S, Shi L, Hirano N, Ban H, Kumagai T, Tatematsu M: Anti-inflammatory effects of caffeic acid phenethyl ester (CAPE), a nuclear factor-kappaB inhibitor, on helicobacter pylori-induced gastritis in mongolian gerbils. Int J Cancer 2009, 125:1786-1795.

18. Fesen MR, Pommier Y, Leteurtre F, Hiroguchi S, Yung J, Kohn KW: Inhibition of HIV-1 integrase by flavones, caffeic acid phenethyl ester (CAPE) and related compounds. Biochem Pharmacol 1994, 48:595-608.

19. Lee KW, Kang NJ, Kim JH, Lee KM, Lee DE, Hur HJ, Lee HJ: Caffeic acid phenethyl ester inhibits invasion and expression of matrix metalloproteinase in SK-Hep1 human hepatocellular carcinoma cells by targeting nuclear factor kappa B. Genes Nutr 2008, 2:319-322.

20. Velazquez C, Navarro M, Acosta A, Angulo A, Dominguez Z, Robles R, Robles-Zepeda R, Lugo E, Goycoolea FM, Velazquez EF, Astiazaran H, Hernandez J: Antibacterial and free-radical scavenging activities of sonoran propolis. J Appl Microbiol 2007, 103:1747-1756.

21. Okutan H, Ozcelik N, Yilmaz HR, Uz E: Effects of caffeic acid phenethyl ester on lipid peroxidation and antioxidant enzymes in diabetic rat heart. Clin Biochem 2005, 38:191-196.

22. Cicala C, Morello S, lorio C, Capasso R, Borrelli F, Mascolo N: Vascular effects of caffeic acid phenethyl ester (CAPE) on isolated rat thoracic aorta. Life Sci 2003, 73:73-80.
23. Hishikawa K, Nakaki T, Fujita T: Oral flavonoid supplementation attenuates atherosclerosis development in apolipoprotein E-deficient mice. Arterioscler Thromb Vasc Biol 2005, 25:442-446.

24. Tamer L, Sucu N, Ercan B, Unlu A, Calikoglu M, Bilgin R, Degirmenci U, Atik $U$ : The effects of the caffeic acid phenethyl ester (CAPE) on erythrocyte membrane damage after hind limb ischaemia-reperfusion. Cell Biochem Funct 2004, 22:287-290.

25. Celik S, Erdogan S, Tuzcu M: Caffeic acid phenethyl ester (CAPE) exhibits significant potential as an antidiabetic and liver-protective agent in streptozotocin-induced diabetic rats. Pharmacol Res 2009, 60:270-276.

26. Hsu FL, Chen YC, Cheng JT: Caffeic acid as active principle from the fruit of xanthiumstrumarium to lower plasma glucose in diabetic rats. Planta Med 2000, 66:228-230.

27. Fuliang HU, Hepburn HR, Xuan H, Chen M, Daya S, Radloff SE: Effects of propolis on blood glucose, blood lipid and free radicals in rats with diabetes mellitus. Pharmacol Res 2005, 51:147-152.

28. Matsui T, Ebuchi S, Fujise T, Abesundara KJ, Doi S, Yamada H, Matsumoto K: Strong antihyperglycemic effects of water-soluble fraction of brazilian propolis and its bioactive constituent, 3,4,5-tri-O-caffeoylquinic acid. Biol Pharm Bull 2004, 27:1797-1803.

29. Tolan I, Ragoobirsingh D, Morrison EY: Isolation and purification of the hypoglycaemic principle present in capsicum frutescens. Phytother Res 2004, 18:95-96.

30. Mahesh T, Sri Balasubashini MM, Menon VP: Photo-irradiated curcumin supplementation in streptozotocin-induced diabetic rats: effect on lipid peroxidation. Therapie 2004, 59:639-644.

31. Yang J, Kerwin SM, Bowman PD, Stavchansky S: Stability of caffeic acid phenethyl amide (CAPA) in rat plasma. Biomed Chromatogr 2012, 26:594-598.

32. Yang J, Marriner GA, Wang X, Bowman PD, Kerwin SM, Stavchansky S: Synthesis of a series of caffeic acid phenethyl amide (CAPA) fluorinated derivatives: comparison of cytoprotective effects to caffeic acid phenethyl ester (CAPE). Bioorg Med Chem 2010, 18:5032-5038.

33. Nishioka TW, Kawabata J, Niki J, Niki R: Isolation and activity of N-p -coumaroyltyramine, an a-glucosidase inhibitor in welsh onion (allium fistulosum). Biosci Biotechnol Biochem 1997, 61:4

34. Yamazaki Y, Kawano Y, Uebayasi M: Induction of adiponectin by natural and synthetic phenolamides in mouse and human preadipocytes and its enhancement by docosahexaenoic acid. Life Sci 2008, 82:290-300.

35. Weng YC, Chiu HL, Lin YC, Chi TC, Kuo YH, Su MJ: Antihyperglycemic effect of a caffeamide derivative, KS370G, in normal and diabetic mice. J Agric Food Chem 2010, 58:10033-10038.

36. Weng YC, Chuang CF, Chuang ST, Chiu HL, Kuo YH, Su MJ: KS370G, A synthetic caffeamide derivative, improves left ventricular hypertrophy and function in pressure-overload mice heart. Eur J Pharmacol 2012, 684:108-115.

37. Chi TC, Ho YJ, Chen WP, Chi TL, Lee SS, Cheng JT, Su MJ: Serotonin enhances beta-endorphin secretion to lower plasma glucose in streptozotocin-induced diabetic rats. Life Sci 2007, 80:1832-1838

38. Ku PM, Chen L, Liang JR, Cheng KC, Li YX, Cheng JT: Molecular role of GATA binding protein 4 (GATA-4) in hyperglycemia-induced reduction of cardiac contractility. Cardiovasc Diabetol 2011, 10:57.

39. Katovich MJ, Meldrum MJ, Vasselli JR: Beneficial effects of dietary acarbose in the streptozotocin-induced diabetic rat. Metabolism 1991, 40:1275-1282

40. Johansen O, Vaaler S, Jorde R, Reikeras O: Increased plasma glucose levels after hypnorm anaesthesia, but not after pentobarbital anaesthesia in rats. Lab Anim 1994, 28:244-248.

41. Chi TC, Chen WP, Chi TL, Kuo TF, Lee SS, Cheng JT, Su MJ: Phosphatidylinositol-3-kinase is involved in the antihyperglycemic effect induced by resveratrol in streptozotocin-induced diabetic rats. Life SCi 2007, 80:1713-1720.

42. Ehses JA, Lacraz G, Giroix MH, Schmidlin F, Coulaud J, Kassis N, Irminger JC, Kergoat M, Portha B, Homo-Delarche F, Donath MY: IL-1 antagonism reduces hyperglycemia and tissue inflammation in the type 2 diabetic GK rat. Proc Natl Acad Sci USA 2009, 106:13998-14003.

43. Chi TC, Lee SS, Su MJ: Antihyperglycemic effect of aporphines and their derivatives in normal and diabetic rats. Planta Med 2006, 72:1175-1180.

44. Bernier M, Curtis MJ, Hearse DJ: Ischemia-induced and reperfusioninduced arrhythmias: importance of heart rate. Am J Physiol 1989, 256: $\mathrm{H} 21-31$ 
45. Lee AS, Chen WP, Su MJ: Comparison of the cardiac electrophysiological effects between doxazosin and bunazosin. J Biomed Sci 2008, 15:519-528.

46. Chiao CW, da Silva-Santos JE, Giachini FR, Tostes RC, Su MJ, Webb RC: P2X7 Receptor activation contributes to an initial upstream mechanism of lipopolysaccharide-induced vascular dysfunction. Clin Sci (Lond) 2013, 125:131-141.

47. Ulker S, Cinar MG, Bayraktutan U, Evinc A: Aprotinin impairs endotheliumdependent relaxation in rat aorta and inhibits nitric oxide release from rat coronary endothelial cells. Cardiovasc Res 2001, 50:589-596.

48. Yu X, Tesiram YA, Towner RA, Abbott A, Patterson E, Huang S, Garrett MW, Chandrasekaran S, Matsuzaki S, Szweda LI, Gordon BE, Kem DC: Early myocardial dysfunction in streptozotocin-induced diabetic mice: a study using in vivo magnetic resonance imaging (MRI). Cardiovasc Diabetol 2007, 6:6.

49. Wei M, Ong L, Smith MT, Ross FB, Schmid K, Hoey AJ, Burstow D, Brown L: The streptozotocin-diabetic rat as a model of the chronic complications of human diabetes. Heart Lung Circ 2003, 12:44-50.

50. Proks P, Reimann F, Green N, Gribble F, Ashcroft F: Sulfonylurea stimulation of insulin secretion. Diabetes 2002, 51(Suppl 3):S368-376.

51. Kendall DM, Kim D, Maggs D: Incretin mimetics and dipeptidyl peptidaseIV inhibitors: a review of emerging therapies for type 2 diabetes. Diabetes Technol Ther 2006, 8:385-396.

52. Ferlito S, Puleo F, Carra G, Damante G, Di Vincenzo S, Del Campo F: Effect of alpha-1-blockade by prazosin on blood sugar, insulin and glucagon levels in normals and non-insulin dependent diabetics. J Endocrinol Invest 1983, 6:199-202.

53. Cavallo-Perin P, Bruno A, Cassader M, Cesco L, Gruden G, Pagano G: The glucoregulatory and antilipolytic actions of insulin in abdominal obesity with normal or impaired glucose tolerance: an in vivo and in vitro study. Eur J Clin Invest 1992, 22:725-731.

doi:10.1186/1475-2840-12-99

Cite this article as: Ho et al:: Caffeic acid phenethyl amide improves glucose homeostasis and attenuates the progression of vascular dysfunction in Streptozotocin-induced diabetic rats. Cardiovascular Diabetology 2013 12:99.

\section{Submit your next manuscript to BioMed Central and take full advantage of:}

- Convenient online submission

- Thorough peer review

- No space constraints or color figure charges

- Immediate publication on acceptance

- Inclusion in PubMed, CAS, Scopus and Google Scholar

- Research which is freely available for redistribution 